\title{
UHAMKA MARKETING STRATEGY TO IMPROVE STUDENT LITERACY ${ }^{1}$
}

\author{
Guwido Nur Rahmawati, Dr. Mirza, ST., MM \\ Management Postgraduate Masters, \\ Mercbuana University, UMB, Jakarta, Indonesia
}

DOI: $10.37648 /$ ijrst.v10i02.004

Received: 02 ${ }^{\text {nd }}$ February, 2020; Accepted: 19 ${ }^{\text {th }}$ March, 2020; Published: $27^{\text {th }}$ April, 2020

\begin{abstract}
According to UNESCO, Indonesia world literacy is in second place from the bottom with a percentage of $0.0001 \%$. Some literature says that there are many factors that affect reading interest, including Parents, Motivation, ICT Development, Library Facilities, and Higher Education Curriculum. Based on the literature study results it is necessary for researchers to find out, analyze and re-examine the influence of these factors. This study uses a survey-questionnaire method with accidental sampling technique. The study population was active students at the Pharmacy and Science Faculty of UHAMKA, with a sample of 95 respondents. The analysis technique used is multiple linear regression using SPSS IBT 24.0 application. The results obtained are variables Parents, Motivation, ICT Development, Library Tools. A positive but not significant effect. Unlike the college curriculum which has a positive also significant effect. Simultaneously all variables have a positive effect on reading interest. The study results expected to be input for the Pharmacy and Science Faculty to further improve student literacy. In addition, next research is expected to examine other factors that affect students interest in reading.
\end{abstract}

Keywords: Student Literacy; Reading Interest; Parents; Motivation; ICT Development; Library Facilities; Higher Education Curriculum

\footnotetext{
${ }^{1}$ How to cite the article: Rahmawati G.N., Dr. Mirza, Uhamka Marketing Strategy to Improve Student Literacy, IJRST, Apr-Jun 2020, Vol 10, Issue 2, 24-31, DOI: http://doi.org/10.37648/ijrst.v10i02.004
} 


\section{INTRODUCTION}

Science and technologydevelopment has an impact on the state through the improvement of human thinking ability. Competition between countries could increased through education, so education should now be directed in developing human resources to compete with other countries. This expectation can be achieved if school education is not only aimed at creating students in cognitive aspects (knowledge), but also improved the way students think. This thinking ability can be achieved through by reading process (Harsiati, 2012) in Abrori (2018). Reading is an activity of gaining knowledge that can improve student skills. Without the studentsknowledge not only obtain the maximum new. Reading skill is one of factors that influences student's scientific skills consistently (Hadi and Mulyatiningsih, 2009) in Abrori (2018).

Based on the research results conducted by UNESCO that Indonesia ranks second from the bottom of the matter of world literacy. Where interest in reading Indonesia is at $0,0001 \%$, which means that of 1000 Indonesians only 1 person determined in reading. This can be interpreted that reading interest of Indonesian people is very low. Besides that, based on the research results conducted by Central Connecticut State University in 2016 stated that Indonesia ranked 60 out of 61 countries in reading interest issues (www.kominfo.go.idaccessed on November 22, 2019).

The low interest in reading has an effect on Indonesia's educational life in the world eyes. Indonesia's education level in global competition is very low, this can be seen from Indonesia ranking 62 nd out of 72 countries in the sciencefield, while in mathematics, Indonesia ranks 64th out of 72 countries (http://news.okezone.comaccessed on November 22, 2019). Low literacy becomes fundamental problem that has a very broad impact on the nationprogress. Low literacy will contribute to the low productivity of the nation, which in turn leads to low welfare which is marked by low income per capita. Therefore special efforts from the government are needed to increase the level of Indonesian literacy including: (1) Recruiting and improving the quality of teachers in line with the Mucat agreement in 2006, where the target is in 2030 all students by qualified teachers, professionally trained, have motivation, and get support: (2) Addressing nutrition problems as early as possible where the government allocates an education budget of 441 trillion in 2018 , some of the funds are diverted to nutrition improvement programs through the provision of added food at school; (3) Building and improving educational infrastructure in the electricity, library, computer lab, and ICT infrastructure improvementform; (4) Re-entering mandatory reading books in this curriculum to ensure the availability of quality reading books for schools; (5) The program carried out by the Ministry of Research, Technology and Higher Education to improve reading among students is a collaboration program between the government and the Tanoto Foundation. The program emphasizes prospective teachers who are considered capable of becoming key figures driving literacy (theconverssation.com). However, the above program has not maximally increased Indonesian literacy reading, especially in DKI Jakarta.

One of the analysis studies of Indonesian literacy reading, especially Jakarta, the author conducted research on students at the UHAMKA Pharmacy and ScienceFaculty in Jakarta about what factors influenced student's reading interest. The author previously conducted a pre-survey of 30 respondents (UHAMKA Pharmacy and ScienceFaculty's students) and the results are in Table 1.1 below.

Table. 1.1 Pre-Survey Results

\begin{tabular}{|l|l|}
\hline $\begin{array}{l}\text { Students ReadingInterestLevel of Pharmacy and } \\
\text { Science Faculty UHAMKA }\end{array}$ \\
\hline Interested & $93 \%$ \\
\hline Not Interested & $0 \%$ \\
\hline Not Answering & $7 \%$ \\
\hline $\begin{array}{l}\text { Reading Students Frequency of Pharmacy and Science } \\
\text { Faculty UHAMKA }\end{array}$ \\
\hline Every Day & $37 \%$ \\
\hline
\end{tabular}




\begin{tabular}{|l|l|}
\hline $1 \mathrm{x}$ A Week & $13 \%$ \\
\hline $2 \mathrm{x}$ A Week & $23 \%$ \\
\hline $3 \mathrm{x}$ A Week & $20 \%$ \\
\hline 1x A Month & $7 \%$ \\
\hline $2 \mathrm{x}$ A month & $0 \%$ \\
\hline $3 \mathrm{x}$ A month & $0 \%$ \\
\hline Never & $0 \%$ \\
\hline
\end{tabular}

Interest Type Reading

\begin{tabular}{|l|l|}
\hline Indonesia Books Subject & $21 \%$ \\
\hline English Textbooks & $5 \%$ \\
\hline Journals & $12 \%$ \\
\hline Novels & $32 \%$ \\
\hline Magazines & $9 \%$ \\
\hline Newspapers & $2 \%$ \\
\hline Comics & $14 \%$ \\
\hline Others & $5 \%$ \\
\hline Media &
\end{tabular}

\begin{tabular}{|l|l|}
\hline Online Reading & $56 \%$ \\
\hline Reading Text Books & $44 \%$ \\
\hline
\end{tabular}

Visit to LibraryFrequency

\begin{tabular}{|l|l|}
\hline Very Frequently & $23 \%$ \\
\hline Frequent & $57 \%$ \\
\hline Rarely & $17 \%$ \\
\hline Very Rarely & $3 \%$ \\
\hline Stent Activity in L
\end{tabular}

Student Activity in Library

\begin{tabular}{|l|l|}
\hline Borrowing and Reading Books & $32 \%$ \\
\hline Working on Tasks & $44 \%$ \\
\hline Borrowing Books Only & $6 \%$ \\
\hline Looking for Journals & $10 \%$ \\
\hline Reading Final Project (Thesis) & $8 \%$ \\
\hline M
\end{tabular}

Media Search Information

\begin{tabular}{|l|l|}
\hline Search Engine & $35 \%$ \\
\hline Website / Application & $25 \%$ \\
\hline Print Media & $9 \%$ \\
\hline Electronic Media & $3 \%$ \\
\hline Books and Journals & $28 \%$ \\
\hline
\end{tabular}

Source: Prasurvey Questionnaire

Based on the surveyresults conducted can be seen at a Table 1.1 shows that the majority of UHAMKA Pharmacy and ScienceFaculty students are interested in reading about $93 \%$. While the frequency number of students doing reading activities every day is $37 \%$. Students like to read, but the type of reading that is often read is not reading that supports their information needs, most of which they read are novels 
by $32 \%$. Whereas the interest to read lecture literature books and journal publications, both in Indonesian and English, is very low $21 \%$ for Indonesian language books, 5\% for English language books and 12\% for journal publications. This is because students of Pharmacy and Science Faculty often read online, which is $56 \%$. Regarding the frequency of students visits in UHAMKA Pharmacy and Science Faculty to the library is very rare $(57 \%)$, while if there is an activity that is often done by UHAMKA Pharmacy and ScienceFaculty students in the library is doing assignments (44\%), as well as borrowing and reading books related to the eye lecture $(32 \%)$. So the results of the pre-survey above can be concluded that the reading interest of students in theUHAMKA Pharmacy and Science Faculty is low. This could be due to the impact of the development of ICT (Information Communication Technology) which influenced changes in information seeking behavior that initially used print media (textbooks) changed in information search through digital media (search enggine, website). This was seen from majority pre-survey results of UHAMKA Pharmacy and ScienceFaculty students use information search through $35 \%$ search engine and $25 \%$ website or application. There are several programs that have been carried out at UHAMKA Pharmacy and Science Faculty to increase student literacy but have not been successful including (1) Students required to have books every course, but are not necessarily read; (2) Students are required to read the literature in completing process the final project, but in other lecture processes students are not required to read the literature before lectures begin. Based on the survey results above, it is necessary for researchers to conduct research on increasing reading interest in UHAMKAPharmacy and ScienceFacultyby taking into account Family, Motivation, ICT Effects, Complete Library Facilities, and Education Curriculum. These five factors are considered as the biggest determinant in increasing reading interest.

\section{RESEARCH METHODS}

The research type is quantitative with survey explanatory research methods. Data were obtained by survey instrument using a questionnaire. This studyused primary data obtained from respondents, namely active students of UHAMKA Pharmacy and Science Faculty through surveys with questionnaires, in addition it was supported by secondary data obtained from relevant agencies and sources.

The study population was active students of Pharmacy and Science Faculty by taking samples using the Slovin formula with a value of $\mathrm{e}=10 \%$ so that the sample in this study amounted to 95 respondents. The sampling technique used is non probabilistic rather random sampling. The analytical method used is descriptive analysis with multiple linear regression using the SPSS IBT 24.0 application. The multiple linear regression model is explained with the following equation:

$$
\begin{aligned}
& \mathrm{Y}=\alpha+\beta 1 \mathrm{X} 1+\beta 2 \mathrm{X} 2+\beta \mathrm{n} \mathrm{Xn}+\mathrm{e} \\
& \text { Description: } \\
& \mathrm{Y}=\text { Dependent variable. } \\
& \mathrm{X}=\text { free variable. } \\
& \alpha=\text { Constant. } \\
& \beta=\text { Slope or estimated coefficient }
\end{aligned}
$$


Based on the above explanation so that the research model can be seen in the figure below

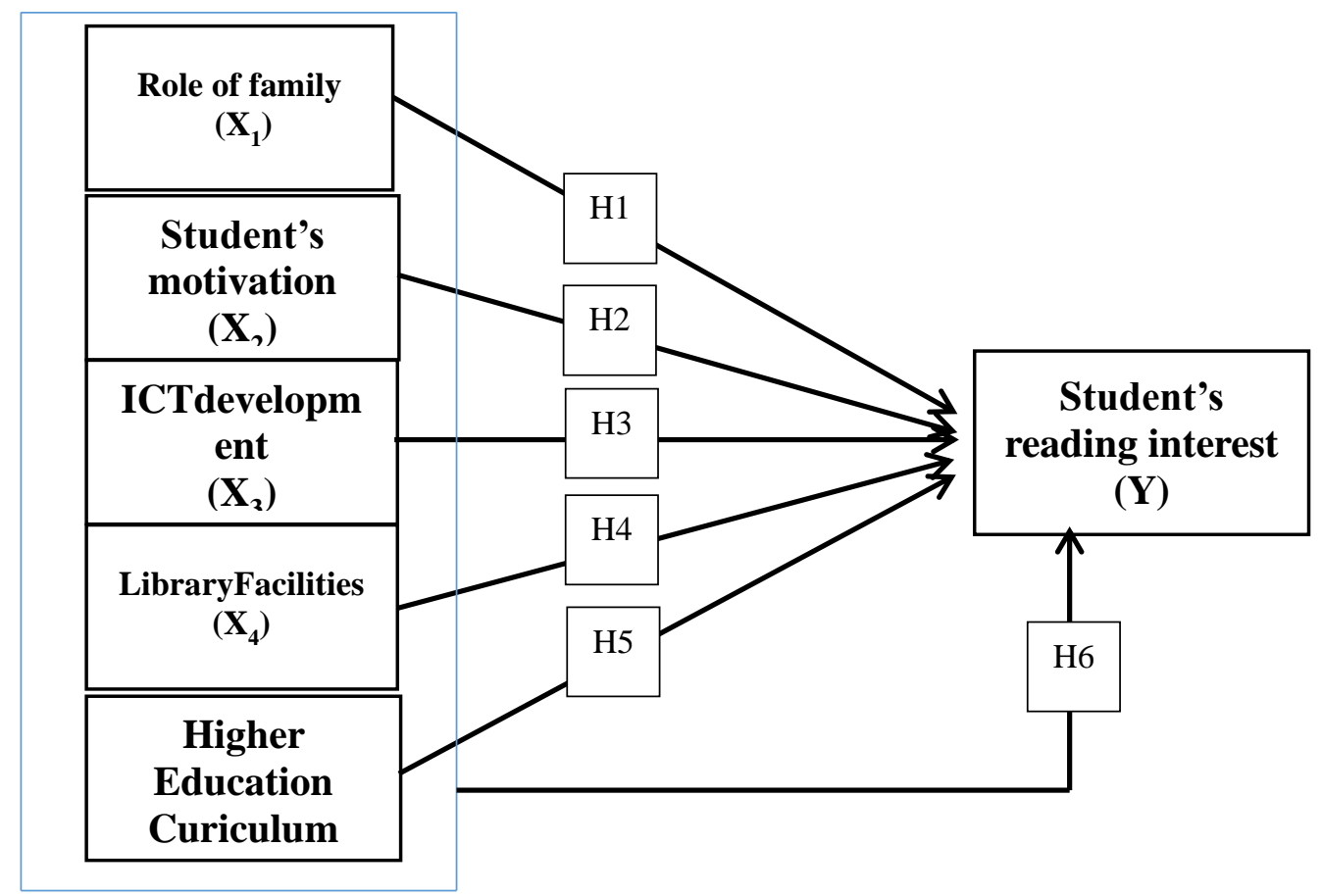

Figure 1.1 Research Model

\section{RESULTS}

\section{Respondent Profile}

Based on the results of descriptive statistical data about the respondent's profile can be seen in Table 1.2 below.

Table 1.2 Respondent Profile

\begin{tabular}{|l|l|l|}
\hline Information & Frequency & Percentage \\
\hline Gender & 26 & $27.36 \%$ \\
\hline Male & 69 & $72.63 \%$ \\
\hline Female & 95 & $100 \%$ \\
\hline Total & 1 & $1 \%$ \\
\hline Domicile & 3 & $3.15 \%$ \\
\hline North Jakarta & 42 & $44.2 \%$ \\
\hline South Jakarta & 3 & $3,15 \%$ \\
\hline East Jakarta & 3 & $3.15 \%$ \\
\hline West Jakarta & 3 & $1 \%$ \\
\hline Jakarta Pusat & 1 & $7.36 \%$ \\
\hline Depok & 7 & $3.15 \%$ \\
\hline Tangerang & 3 & $33.68 \%$ \\
\hline Bogor & 32 & $100 \%$ \\
\hline Bekasi & 95 & $2.5 \%$ \\
\hline Total & \multicolumn{2}{|l|}{} \\
\hline Age & 4 & \\
\hline Less than 18 Years &
\end{tabular}




\begin{tabular}{|l|l|l|}
\hline $18-24$ Years & 80 & $84.2 \%$ \\
\hline $25-35$ Years & 11 & $11.5 \%$ \\
\hline Total & 95 & $100 \%$ \\
\hline & \multicolumn{2}{|l|}{} \\
\hline Status & 4 & $4.2 \%$ \\
\hline Married & 92 & $94.7 \%$ \\
\hline Not/ Not Married & 92 & $1 \%$ \\
\hline Widow / widower & 1 & $100 \%$ \\
\hline Total & 95 & \\
\hline
\end{tabular}

This research data obtained from 95 respondents who are active students in UHAMKA Pharmacy and Science Faculty. The respondents's gender in this study were $27.36 \%$ male and $72.63 \%$ were female. Resident dominance is dominant in East Jakarta with a percentage of $44.21 \%$ because it is adjacent to the campus area of UHAMKA Pharmacy and Science Faculty, Bekasi by $33.68 \%$, Tangerang by $7.36 \%$, South Jakarta, West Jakarta and Central Jakarta respectively by $3.15 \%$. While North Jakarta and Depok each with $1 \%$. The respondents's age in this study is between 18-24 years, that is $84.2 \%, 25-35$ years are $11.5 \%$ and those whose age is less than 18 years are $2.5 \%$. For marital status $4.2 \%$ answered they were married, $94.7 \%$ single and $1 \%$ widowed. It can be concluded that the majority of respondents are women, with a productive age so that they have the characteristics of discipline, diligent, resilient as seen from reading fondness.

\section{Regression Test Results}

This study uses linear regression that is partially and simultaneously. Partial test or t-test was conducted to determine how far the influence of each independent variable that the family's role $\left(\mathrm{X}_{1)}\right.$, Motivation $\left(\mathrm{X}_{2)}, \mathrm{ICT}\right.$ development $\left(\mathrm{X}_{3)}\right.$,Library's Support $\left(\mathrm{X}_{4}\right)$ and the Higher Education Curriculum $\left(\mathrm{X}_{5}\right)$ partially or individually in explaining variabel bound Interest in Reading (Y) by looking at the coefficient $\beta$. While the simultaneous test is carried out to find out how far the influence of independent variables, Family $\left(\mathrm{X}_{1}\right)$, Motivation $\left(\mathrm{X}_{2}\right)$, ICT Development $\left(\mathrm{X}_{3}\right)$, Library Facilities $\left(\mathrm{X}_{4}\right)$ and Higher Education Curriculum $\left(\mathrm{X}_{5}\right)$ together explain variables bound, interest in reading (Y) with Farithmetic. The regression testresults can be seen in Table 1.3 below.

Table. 1.3 Test Results of Multiple Linear Regression

\begin{tabular}{|c|c|c|c|c|c|c|}
\hline \multirow{2}{*}{\multicolumn{2}{|c|}{ Model }} & \multicolumn{2}{|c|}{$\begin{array}{l}\text { Unstandardized } \\
\text { Coefficients }\end{array}$} & \multirow{2}{*}{$\begin{array}{l}\text { Standardized } \\
\text { Coefficients } \\
\text { Beta }\end{array}$} & \multirow{2}{*}{$\mathrm{T}$} & \multirow{2}{*}{ Sig. } \\
\hline & & B & $\begin{array}{l}\text { Std. } \\
\text { Error }\end{array}$ & & & \\
\hline \multirow[t]{6}{*}{1} & (Constant) & .883 & .404 & & 2.186 & .031 \\
\hline & Parents & .191 & .099 & .186 & 1.924 & .058 \\
\hline & Motivation & .178 & .091 & .187 & 1.942 & .055 \\
\hline & ICT & .028 & .045 & .051 & .630 & .530 \\
\hline & Library Facilities & .020 & .067 & .025 & .291 & .772 \\
\hline & Curriculum & .339 & .074 & .426 & 4.591 & .000 \\
\hline
\end{tabular}




\begin{tabular}{|l|l|l|l|}
\hline 2 & $\mathrm{R}^{2}$ & .445 & \\
\hline 3 & Fcount & 14.271 & \\
\hline
\end{tabular}

Source: SPSS Analysis Results 24.0

From Table 1.3 above, it can be seen the regression results equation that is generated, namely: $\mathrm{Y}=0.883+0.191 \mathrm{X}_{1}+0.178 \mathrm{X}_{2}+0.028 \mathrm{X}_{3}+0.020$ $\mathrm{X}_{4}+0.339 \mathrm{X}_{5}$ which can be interpreted as follows:

1. Constant $\mathrm{a}=0.883$. If the Family $\left(\mathrm{X}_{1}\right)$ Motivation $\left(\mathrm{X}_{2}\right)$, ICT Development $\left(\mathrm{X}_{3}\right)$, Library Facilities $\left(\mathrm{X}_{4}\right)$, Higher Education Curriculum $\left(\mathrm{X}_{5}\right)$ are considered zero (none) then the student interest in reading is worth 0.0883 units.

2. Based on hypothesis acceptance terms that is if $\mathrm{t}$ arithmetic $>\mathrm{t}$ table or (-) $\mathrm{t}$ arithmetic $<(-) \mathrm{t}$ table or sig value $\alpha<\alpha 0.05$, so that all hypotheses are accepted. The positive $\beta$ coefficient value means that if the value of $X$ increases, the $\mathrm{Y}$ value will also increase, conversely if the negative $\beta$ coefficient value means that if the value of $\mathrm{X}$ rises, the $\mathrm{Y}$ value will decrease.

a. Family variable $\left(\mathrm{X}_{1}\right)$ has $\operatorname{sig} \alpha=0.058>\alpha=$ 0.05 then the Family variable $\left(\mathrm{X}_{1}\right)$ has an effect but is not significant. Large family influence on reading interest of 0.191 . This shows that the direction of the relationship between parents $\left(\mathrm{X}_{1}\right)$ with interest in reading students (Y) is positive with a small effect value.

b. The motivation variable $\left(\mathrm{X}_{2}\right)$ has sig $\alpha=$ $0.055>\alpha=0.05$, so the Motivation variable $\left(\mathrm{X}_{2}\right)$ has an effect but is not significant. The value of the influence of motivation variables on reading interest is 0.178 This shows that the direction of the relationship between motivation $\left(\mathrm{X}_{2}\right)$ with student reading interest $(\mathrm{Y})$ is positive with a small effect value.

c. The influence variable ICT $\left(\mathrm{X}_{3}\right)$ has sig $\alpha=$ $0.530>\alpha=0.05$, so the Motivation variable $\left(\mathrm{X}_{3}\right)$ influences but is not significant. The value of the influence of the motivation variable on reading interest is 0.028 This shows that the direction of the relationship between the development of ICT $\left(\mathrm{X}_{3}\right)$ with the reading interest of students $(\mathrm{Y})$ is positive with a very small effect value.

d. The library facilities variable $\left(\mathrm{X}_{4}\right)$ has $\operatorname{sig} \alpha=$ $0.772>\alpha=0.05$, so the Motivation variable $\left(\mathrm{X}_{4}\right)$ has an effect but is not significant. The value of the influence of motivation variables on reading interest is 0.020 . This shows that the direction of the relationship between the library facilities $\left(\mathrm{X}_{4}\right)$ with the students interest in reading ( $\mathrm{Y}$ ) is a positive value effect is very small.

e. College curriculum variable $\left(\mathrm{X}_{5}\right)$ has sig $\alpha=$ $0,000<\alpha=0.05$, so the Motivation variable $\left(\mathrm{X}_{5}\right)$ has a significant effect. The amount of influence is 0.339 . This shows that the direction of the relationship between motivation $\left(\mathrm{X}_{5}\right)$ and student reading interest $(\mathrm{Y})$ is positive and large.

\section{CONCLUSIONS AND SUGGESTIONS Conclusions}

1. Higher education curriculum factors have the highest influence on reading interest with a value of 0,000 ( 0.0 percent). This can prove that the role of higher education curriculum in teaching activities has a high influence on the growth of students' reading interest. Therefore, in formulation or curriculum review, UHAMKA management must pay more attention so that the target of students having an interest in reading can be fulfilled

2. The motivation factor has the second highest influence on student reading interest by 0.055 ( 5.5 percent) so that the UHAMKA management needs to work with people parents, and other parties in order to foster student motivation to read.

3. Parent factor has the third highest influence on interest in reading with a value of 0.058 (5.8 percent). So UHAMKA management needs to take the opportunity to form a positioning strategy in the form of a change of trust in new parents to entrust their children in the hope of changing their behavior towards reading interest.

4. ICT development factor has the second lowest influence on reading interest after higher education curriculum, the value is 0.530 (5.3 percent). So the UHAMKA management needs to create and formulate a new strategy in terms of using ICT for students on campus.

5. Library facilities factor has the lowest effect after the parents factor on students' reading interest 
with a value of 0.772 (7.72 percent). The availability of sufficient library facilities can trigger the growth of student'sreadinginterest. So UHAMKA management is expected to have more attention to the improvement of facilities, especially library facilities.

\section{Suggestions}

This research is focused on reading interest at the faculty level of UHAMKA only. So that for further research data can be taken at all faculties in UHAMKA. Additionally, based on the results of the $\mathrm{R}^{2}$ values obtained using multiple linear regression analysis with a value of 0.445 (44.5 percent), so it can be interpreted that this research model is not fit perfectly because below 0.5 (50 percent). So for further researchers need to examine other factors that influence interest in reading in addition to the factors examined in this study. Other factors are gender, friends, language, and teacher.

\section{REFERENCE}

[1] Abrori. (2018). Improving Reading Literacy Strategy through Seven Programs of Reading Interest complying Da'wah Message. Attarbiyah: Journal of Islamic Culture and Education, 3(2), 205-225. https://doi.org/10.18326/attarbiyah.v3i2.205-225

[2] Pharmacy and Science Faculty UHAMKA. (2019). Data of Active Students of PharmacyFaculty in 2019.

[3] Riadi, Edi. (2016). Research Statistics (Manual Analysis and IBM SPSS). Issue 1. Yogyakarta: ANDI.

[4] Santoso, R. (2018). The Effect of School Literacy Programs on Student's Reading Interest in SMA 2 Gadingrejo Academic Year 2017/2018. Lampung University.

[5] www.kominfo.go.id. Accessed on 22 November 2019. At 14:30 WIB 